\section{Cellulase and Chitinase in Soil Amœbæ}

IT has long been known that cellulose and chitin are broken down by many species of both bacteria and fungi that can be isolated from soil. It is probable that the soil fauna may also be important in this respect, for it is known that earthworms and eelworms may possess both cellulase and chitinase ${ }^{1}$. Some soil amœbæ were examined to see whether they, too, possessed these enzymes.

'Pure mixed' cultures (a single species of amœba feeding on a single species of bacteria) of three species of soil amœbæ ${ }^{2}$ grown on non-nutrient agar were harvested, ground between the surfaces of a standard ground-glass joint and incubated with toluene overnight. The extracts were centrifuged and the supernatants examined for the presence of cellulase and chitinase. The bacteria used as food were soil organisms that had been shown to produce neither of the enzymes when grown under similar conditions in the absence of amobæ. Cellulase activity was detected by following the production of reducing sugar from a solution of sodium carboxymethylcellulose at $p \mathrm{H} 5$, or from a suspension of finely divided cellulose precipitated by dilution of a cellulose dispersal in syrupy phosphoric acid. Chitinase activity was detected by following the production of acetylglucosamine from a suspension of finely divided Sepia chitin prepared by dilution of a dispersal in concentrated hydrochloric acid. Very little reducing sugar and no acetylglucosamine were formed on incubating the extracts in the absence of substrate.

The results of an experiment in which sodium carboxymethylcellulose was the substrate are shown in Table 1 (the figures for formation of reducing sugar have been corrected by subtraction of the values for appropriate controls). Action of Helix cellulase on this substrate stops when 37 per cent of the substrate weight has appeared as reducing sugar calculated in terms of glucose. The figure for grams reducing sugar produced per gram of total nitrogen in the extract was calculated as a means of comparing the extracts among themselves and with the digestive enzymes of Helix aspersa. Under similar conditions, this figure for pooled digestive juice of the snail is about $50 \mathrm{gm}$. reducing sugar per gm. total snail nitrogen, or at least fifteen times as great as the figure for the amœbæ. The figure for the amœbæ may be expected to be low for the following reasons. All the amoebre were not in the same state of activity, a considerable proportion having begun to encyst some of the total nitrogen of the harvested material was derived from uneaten bacteria or waste products ; and the cellulase of the amœbr may have been in. activated by dilution and mixing of the enzyme with other components of the organisms (the digestive juice of the snail was removed from the digestive tract and not diluted with the components of the remaining tissues). It is possible, therefore, that the amobr may, in terms of activity per gram total nitrogen, have a cellulose-decomposing power of the same order as that of the snail. The extracts were also shown to hydrolyse finely divided cellulose. No increase in the rate of hydrolysis using this substrate was found when $60 \mu \mathrm{gm}$. bovine serum albumin per ml. was added to the assay medium-presumably sufficient protein was already present in the medium to swamp any effect of added protein ${ }^{3}$. The maximum dry weight of amœbæ present in each assay varied from 1 to $5 \mathrm{mgm}$.

\begin{tabular}{|c|c|c|c|}
\hline $\begin{array}{c}\text { Food } \\
\text { organism }\end{array}$ & Amœba & $\begin{array}{l}\text { Reducing sugar } \\
\text { formed (calc. as } \\
\text { glucose) as \% } \\
\text { carboxymethyl- } \\
\text { cellulose after } 13 \\
\text { days incubation }\end{array}$ & $\begin{array}{l}\text { Reducing } \\
\text { sugar (gm.) } \\
\text { formed per } \\
\text { gm. total } \\
\text { nitrogen of ex } \\
\text { tract, } 5 \text { days }\end{array}$ \\
\hline Aerobacter sp. & \multirow{5}{*}{$\begin{array}{l}\text { Hartmanella } \\
\text { glebae } \\
\text { Hartmanella } \\
\text { sp. } \\
\text { Schizopyrenus } \\
\text { erythaenusa } \\
\text { Hartmanella } \\
\text { sp. } \\
\text { Schizopyrenus } \\
\text { erythaenusa }\end{array}$} & 8 & $2 \cdot 5$ \\
\hline & & 17 & $3 \cdot 6$ \\
\hline & & $9 \cdot 5$ & 1.0 \\
\hline $\begin{array}{l}\text { Soil organism } \\
(4002)\end{array}$ & & $19 \cdot 3$ & $3 \cdot 1$ \\
\hline$"$ & & 20 & $1 \cdot 8$ \\
\hline
\end{tabular}

Incubation of finely divided chitin for 17 days at $35^{\circ}$ at $p \mathrm{H} 5$ with amounts of extract similar to those used when cellulose was the substrate resulted in the decomposition of $30-130 \mu \mathrm{gm}$. of chitin. These amounts were about one-fifth of the weight of cellulose broken down under similar conditions.

The amœbæ described are the only soil protozoa that have been shown to possess cellulase and chitinase; but the cellulose-decomposing abilities of ciliates in the ruminant and termite are well known, and it is probable that many other genera of soil protozoa may be active. It would also be of interest to examine some representative mites from this point of view.

I wish to thank Dr. B. N. Singh, without whom this work would have been impossible, and Mr. T. I. Steenson, of the Microbiology Department at Rothamsted, who were each kind enough to supply the cultures used in the experiments described.

$$
\text { M. V. Tracex }
$$

Rothamsted Experimental Station,

Harpenden,

Herts.

Jan. 20.

${ }^{1}$ Tracey, M. V., Nature, 167, 776 (1951); 2nd Int. Cong. Biochem., Paris, Résúmés des Comm. 242 (1952).

${ }^{2}$ Singh, B. N., Phil. Trans. Roy. Soc., B, 236, 405 (1952).

${ }^{3}$ Whittaker, D. R.. Science, 116, 90 (1952). Tracey, M. V., Blochem. Soc. Symposia, 11, 49 (1953).

\section{Extraction of Enchytraeid Worms from a Coniferous Forest Soil}

The ecology of the terrestrial Enchytraeidae has been neglected mainly because of the lack of an adequate technique for assessing population size and partly because of taxonomic difficulties. Recently, Overgaard Nielsen ${ }^{1}$ has described a method for the large-scale extraction of these worms from soil. This consists of heating soil cores in an earthenware cylinder over a water-bath, and driving the worms upwards into a layer of cooled sand on top of the soil. The enchytraeids are then recovered by washing from the sand.

Studying the enchytraeid population of a coniferous forest soil, this method was not found to be satisfactory, despite attention to detail. Too many dead worms were found in the core, particularly in the litter layer. Therefore an attempt was made to improve on the alternative technique mentioned by Nielsen, in which heat is applied from above to soil spread out on a sieve resting in a funnel full of water. The worms present move downwards through the sieve into the funnel and can be drawn off. This technique was developed, using soil cores from a pure 